\title{
Reconstruction of General Education Policy in Universitas Muhammadiyah Yogyakarta
}

\author{
DOI 10.18196/AllJIS.2020.0115.99-113
}

\section{SADAM FAJAR SHODIQ ${ }^{1}$, ABAS ASYAFAH ${ }^{2}$}

Fakultas Agama Islam, Universitas Muhammadiyah Yogyakarta'

Universitas Pendidikan Indonesia ${ }^{2}$

sadamfajarshodiq@fai.umy.ac.id ${ }^{1}$

\begin{abstract}
General education is not a merely portable decoration in university. In recent curriculum of general education, it has collectively played significant role in determining student's success, achievement, retention and graduation. This research, then, aimed to know how far the implementation of MKDU (General education) policy in university, particularly in UMY. Technically, the research method employed in this research was descriptive-qualitative method, using data collection technique by in-depth interview, observation, and documentation. As a result, the findings of this research demonstrate that MKDU policy in UMY was as follows: (1) MKDU was under coordination of Vice Rector of Academic Affairs; (2) MKDU implementation was the responsibility of Head of Study Program respectively; (3) Credit of MKDU was regulated by Rector through Vice Rector of Academic Affairs; (4) Majority of MKDU lecturers was in accordance with their field; (5) MKDU development was performed via regular workshop in university; (6) Besides special courses, values of MKDU were taught in each subject course by sciences integrity.

Keywords: reconstruction, policy, MKDU (General Education)
\end{abstract}

\section{INTRODUCTION}

Typically, academic field commonly admits that general education is an educational concept originally derived from severe university professionalism since the Industrial Revolution. While, epistemologically, the concept comes subsequently from the old Greek of liberal education [1]. A general education, indisputably, has inserted new content into goals of liberal education. Initially, the concept of "general education" was proposed in the beginning of the $19^{\text {th }}$ Century by an American scholar, AS Packard, and later, it was 
developed and reformulated through "free choice" by CW Eliot, "concentration and distribution" by AL Lowell [2].

Since the $20^{\text {th }}$ Century, various scholars have attempted to clarify the concept of general education, but there is no concept attracting more intention than general education does, and there is no concept that can elevate interpretations as many as general education does [3]. Thus, any attempt to identify general education seemingly becomes a tiresome duty. If we analyze from epistemological view, general education is derived from Latin "stadium generale", studying with people coming from all places [4]. In this case, the word "general" within the term of general education is not understood as "accustomed, order," but "for all" in Latin's sense. It means that he/she has democratic feeling, "for all people" than elite education, aimed for exclusive group. It seems, then, that the first interpretation of general education is the broad target of education.

Nonetheless, general education arises to revise any shortage of specialization based-professional education, but there is differed perception related to relationship of both. Following three representative points are: (1) general education and specialization based-education are parallel concepts, (2) specialization based-education is a concept above of general education, and (3) specialization based-education is a concept below general education [5]. Those three perspectives represent different point of view. In general, the first obtains easier reception from people, since it is deliberately in accordance with awakening of general education. Secondly, it is popular in education practice, taking general education as a delusive specialization based-education version. Obviously speaking, it misinterprets reality and results on difficulty of general education to accept sufficient stressing, and, even, dissolves into immateriality. The third is an ideal assessment since university goes toward modernity to seize pure knowledge, and professionalism will remain becoming a main theme of contemporary university.

Practically, in education case, it is useless to underestimate or exaggerate function of general education, and we should consider specialization basededucation and general education as organic organism, as important as and an integral part to achieve objectives of education. This fact shows that general education is not a portable decoration in university, since, no matter how fast human develops, they necessarily muse human's root, substantially objective of general education. A Taiwanese scholar, Huang Junjie, argued that "What is considered as general education is a type of education building 
someone's subjectivity, solving self-liberation, and establishing interdependent relationship between humanistic and natural environment of human existence [6] and a type of education supplementing "human awakening" [1]. Therefore, purpose of general education is to make students build their completely liberal quality, and facilitate their self-liberation and freedom. In short, general education is an educational process to liberate human wisdom and avoid narrow view, ability, and knowledge. The second interpretation of general education, thus, is to liberate individual wisdom and achieve spiritual freedom.

As general education is aimed to "develop actively participating citizen or people in social activity and have social responsibility" developed comprehensively," and "establish social governance", which its contents demand following issues: (1) not only consider concept of universal value given, but also actual condition of state or territory; (2) not only demand wisdom enlightenment in theoretical class, but also manage certain activity class to obtain profound experience; (3) not only stress on humanistic value of education, but also consider sciences; and (4) not only design some basic subject courses, but also develop some developing subject courses, freely chosen by students. It means that comprehensive design of general education content must entail four principles, combining universality and locality, theory and practice, humanities and sciences, and basic and development. In doing so, the third interpretation of general education is an equilibrium of education content.

Those third interpretations of general education, such as a broad target of education, liberating education purpose, and equilibrium of education content, periodically turn as basic consensus on general education. Hence, it becomes collectively stepping stone of our analysis against practice of general education. Recent curriculum of general education, collectively, has played significant role in determining students' success, satisfaction, retention, and graduation. Such curriculum includes basic subject courses of general education, namely Bahasa, history, arts, humanity, mathematics, foreign language, social sciences, physics along with laboratory component. Special subject courses, such as development/refining program, diversity or multicultural, and carrier and academical subject courses are significant component, individually or collectively, from general education for requirement of graduation in some universities. As referred to Laws Number 12 of 2012 on Higher Education, an education having ability to develop sciences and technology 
and producing a civilized, creative, tolerant, democratic, heroic intellectual, scientist, and/or professional in defending truth for national interest is necessary. In Article 35 section 2, curriculum of higher education is a guideline of learning implementation to achieve the goal of university, mandatorily containing following subject courses: a. Religion; b. Pancasila; c. Civic; and d. Bahasa, performed through curricular, cocurricular and extracurricular activity.

\section{RESEARCH METHOD}

This research having been conducted by employing descriptive-qualitative method. Qualitative approach was employed since the researcher would like to observe naturally how the process of policy decision-making on MKDU (General education) in university. Muhammadiyah University of Yogyakarta was research site with research's subjects comprising of stakeholders, such as rector, vice rector, dean, vice dean, head of study program, lecturer, and students, previously having been decided purposively. Data collection technique was done by in-depth interview, observation, and documentation. After the data were collected, analysis using Miles \& Huberman model [7] was utilized, under the following procedures: (1) data collection; (2) data reduction; (3) data displaying; (4) verification/conclusion drawing.

\section{DISCUSSION}

According to Academic Business Process and Quality Point of Curriculum and Learning Process in the Study Program of PAI in UMY, the implementation of Competence based-Curriculum (KBK) had been conducted since 2013. In 2015, there was curriculum adjustment pursuant to KKNI and National Standard of Higher Education (SNPT), turning into Higher Education Curriculum (KPT) focused to optimize development of learning process and information system through strengthening learning outcome and graduates competitiveness, consisting of improvement on practical skills and soft skills quality and learning effectiveness utilizing Student Centered Learning (SCL) model and drafting efficiency of final assignment. Hopefully, graduates of the Study Program of PAl, demonstrated in profile of graduates, had competitiveness in work field.

Review materials were taken (sourced) from discipline of the study program. While, determining review materials was by deciding discipline cluster based on main, supporting, identifier and others related to learning outcome in the Study Program of PAI, based on sciences, technology, and arts. The 
calculation phases were as follows: (1) determining courses' load by stipulating materials' coverage and depth of each learning outcome and review materials of each courses based on Bloom's taxonomy; (2) deciding courses' credit by a mean of dividing courses' load with total of loads of all courses and multiplied by total of credits compulsory achieved within one learning cycle in the study program.

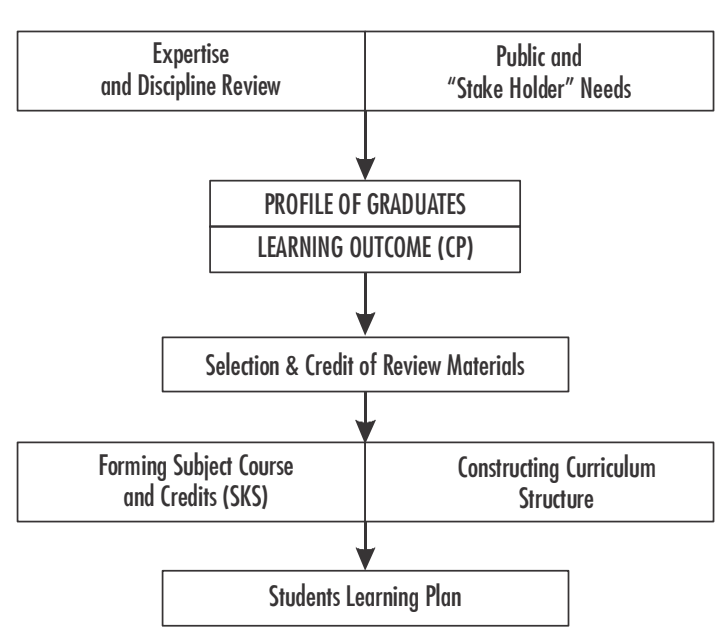

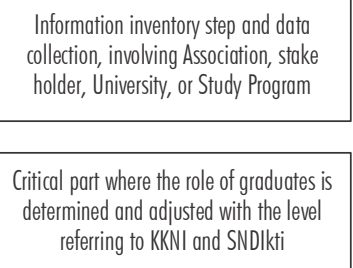

Considering Coverage and Depth of material mastery

Referring to SNDIkti for Credit (SKS) and a series/sequence of review mastery

Selecting a precise strategy and describing graduation indicators

Figure 1. Scheme of Credit Stipulation (as cited from document of Curriculum of Study Program of PAI, UMY)

Basic subject courses, or commonly known as MKDU (General Education) are compulsory taken by students studying in either Undergraduate or Diploma level. Having self-autonomy in designing its curriculum, university can still add other MKDUs to refine learning outcome and desired character building. Muhammadiyah University of Yogyakarta (UMY) implementing Four Principles of Higher Education had also added its MKDU within curriculum structure of university, comprising of English, Entrepreneurship, and Muhammadiyah.

Provisions of MKDU in UMY were as follows: (1) MKDU was under Vice Rector of Academic Affairs; (2) Implementation of MKDU became responsible of Head of Study Program, respectively; (3) Credits of MKDU were regulated by Vice Rector of Academic Affairs on behalf of Rector; (4) Majority of MKDU lecturers was in accordance with their expertise; (5) Development of MKDU was performed through regular workshop in university; (6) Aside of special subject courses, MKDU's values were taught in every subject course 
by discipline integration (the result of document analysis).

\section{Discussion}

The main curriculum of university assumes that the first two years of study is optimal time for personal development significantly, based on historical and scientific knowledge in order to investigate various patterns and values of culture and develop critical thinking and effective communication. Higher education has additional reasons to require taking main course of general education. First, some students have perhaps found a hidden passion on certain major as the result of requirement on taking general education course [8]. After enjoying such class, students may find themselves undergoing lecturing or taking unsuitable major in academic field as they have not considered yet [3]. Second, compulsory subject course ensures that each graduate of university has a series of equally basic tools desired by graduates acquittanced with analytical skills and strong sense of writing and basic knowledge of modern society globally [8].

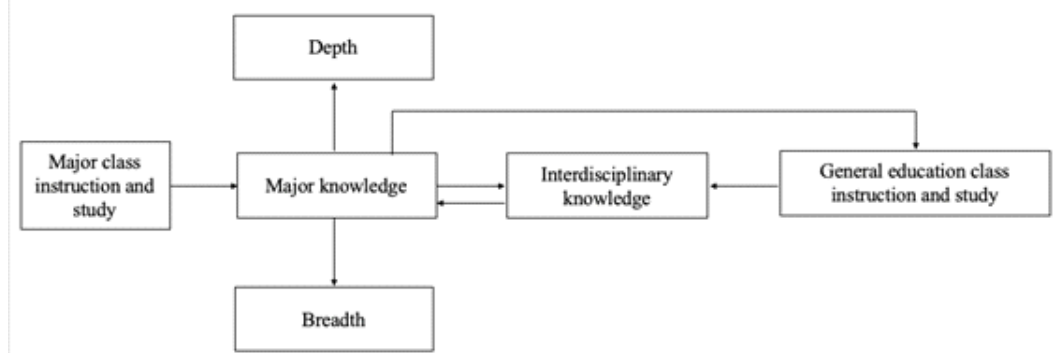

Figure 2. Diagram of general education and main subject courses taking [1].

\section{Curriculum of General Education}

Recently, many undergraduate students in universities must complete about 10 up to 20 credits (SKS) as requirements of main subject course. These credits, minimally 10 up to 20 credits (SKS) can be taken in every undergraduate program, where any students satisfy requirements for registration under guideline stipulated by academic unit of university or department. The basic subject course can broaden students' knowledge and skills outside of their major; such knowledge and skills can be useful in the future [9]. Typically, curriculum of general education minimally comprises of four up to six courses (divided into six semesters), comprising of Bahasa, religion, history, humanity, mathematics, foreign language, social sciences, and physics agama 
along with laboratory component.

For subject course of Bahasa and English, it is compulsory to be taken orderly from similar study program [6]. Curriculum of general education, collectively, has around $10-20 \%$ of Credits (SKS) taken by students before graduation. The subject course of general education is scheduled in the afternoon, evening, weekend, and online as distanced learning program [10].

\section{Special Program (Upgrading)}

Many universities also offer special program (supplement) with a series of advanced subject courses to challenge talented students, particularly in the curriculum of general education. Beside taking basic subject courses, students have also completed a series of supplementary academic standards. Consequently, such subject courses can be officially accepted as special program; minimal credit unit and other administrative requirements must be compulsory to pass from this supplementary program (Lei, personal observation). Any student participating in special program can obtain substantial achievement of self-interpersonal, self-intellectuality, and artistic interest (Astin, 1999). They involving in special program are incliningly more survive in university and expect to graduate soon and achieve professional degree (Astin, 1999). Therefore, special participation has positive correlation with students' satisfaction, retention, and relation of students and faculty (Astin, 1999).

\section{Education Implication}

The recent curriculum of general education in Indonesia usually consists of 10 up to $20 \%$ from undergraduate curriculum of students. Many students, averagely, take 2 up to 4 semesters, including "interim" semester, to complete all subject courses of general education (Lei, personal observation). Students in general are not required to take remedial, supplementary, and carrier courses. However, academic success and multicultural courses or equally have been added as part of general education curriculum in the last few decades. While adding two required courses, any institution can 1) replace existing two basic subject courses with academic success and multicultural subject courses; 2) substitute existing one basic subject course while supplementing academic success and multicultural subject courses; or 3) sufficiently add two new subject courses as part of graduation requirement (Lei, personal observation). Unfortunately, all students enjoy to take these courses, rela- 
tively two subject courses.

\section{Academic success or equal subject courses}

In some universities, lecturers sometimes underestimate students' personalized learning skills, since they usually generalize that students have higher motivation and self-discipline every time [1]. Students' personalized learning skills is significantly successful recipe of any student resulting a relatively higher retention and graduation of students in university. In doing so, multicultural subject courses have been implemented to solve campus diversity and work filed, particularly in this contemporary society. Diversity can be seen publicly along with massive development of computer and technology where companies recruit and maintain high-qualified employees globally in order to maximize human resources and profit. Nowadays, company has ordered its employee to work on various projects under a work team and members of this work team will be appreciated by others based on his/her expertise and skills in English. Therefore, students need to know how to work in a team, how mode of communication develops, how to work cohesively with any individual from different background of culture and language in order to be implemented in work place in future.

In detail, there are some main factors contributing against students' retention and satisfaction in university [11]. Partially, curriculum of general education determines students' retention, satisfaction, and success in institution. Students' satisfaction contributes against motivation, motivation is predicting factor of students' success [12]. The curriculum structure of general education, such as a series of program and total of parallel programs, seems important to motivate students to study regularly [3]. Perhaps, students feel bored and demotivated to study regularly if two or more subject courses have highly similar content, mainly as similar instructors use similar teaching and assessing of such subject courses [13]. Clearly, students' satisfaction and retention is two key variables in determining students' success or failure, subject course, curriculum/program, and university [14]. In short, administrator of university, faculty, and students should satisfy their responsibility respectively; they must also cooperate jointly to produce a directed and healthy academic community in the national level.

\section{Improving Strategies on "Selling Power" of General Educa- tion}


It is easily to find contradiction and issues arising from general education within contemporary universities. In one side, the importance of general education has been continuously affirmed in the goal of education, and, on the other hand, general education has been sustainably weakened and ignored practically [5]. Basic subject course has significant role in general education, particularly "four courses" (Religion, Pancasila, Civic, and Bahasa) having dominant status, but the result of these courses is non-ideal and produces certain restriction effects for other subject courses.

Based on the fact, it is difficult for subject courses under General Education to stimulate students' interest in studying and they cannot fulfill students' practical necessity, so it forms common phenomenon "missing subject course required selectively and missing all options". Here, it seems that design of subject of general education in university has a shortage. There is easily changing of review mechanism on subject courses and students can change from subject course of general education to other subject courses in order to "seize credits." Many universities stipulate remedial test or decide regulation for students who are failed in optional subject course to repeat such subject courses, and students only complete required credits for graduation. Both policies create a status gap between both subject courses and result on students having concept of "level of subject course"-basic subject source required is the most important, general program required is the next, and option is the most minimal or insignificant. People can easily forecast the fate of optional subject courses. Henceforth, it demonstrates that free choice is the biggest risk model in the practice of general education since general education can be ignored simply.

\section{Coping with "Knowledge Centered" Trend in General}

\section{Education}

To satisfy the goal of general education, many universities has selected, optimized, and determined which subject course of general education can be basic subject course, which is the most requested and chosen, and which credit must be managed. In example, Study Program of PAl in Muhammadiyah University of Yogyakarta combined compulsory and optional subject course. There was nothing wrong with those courses, but it was better to think a trend of "knowledge centered" or "discipline centered", shadowing behind [3]. We must show that "knowledge" in "general education" cannot demon- 
strate "knowledge" in all disciplines, but it forms "a wide-range insights and outstanding knowledge" and "knowledge wisdom".

We should present that general education is an education concept established under rationalism guidance, stressing on training through rational mode of thinking, and necessary creating liberated people. In disparity, we usually take general education to collect knowledge. Therefore, Committee of Harvard displayed that "If we consider general education as one-by-one class, it is ashamed" [15], since one subject course cannot automatically form a whole and, thus, it cannot reach the goal of analytical thinking. Such subject courses are easily separated from individual reality and it cannot attract students' interest in order to achieve any success. Also, they can assist popularity of sustainable teaching method as "feeding a duck", obviously contradicted with initial intention of general education. As consequence, there are many universities in Indonesia trying to break purely knowledge centered-education model, establishing in-house institution and higher education, and utilizing life experience to practice general education and breaking the absence of life education in the "first grade class".

\section{Integrating Local Culture in General Education}

As general education stresses on universal content, it also should consider the importance of local knowledge. Local knowledge is often abundant with wisdom and morality. In line with Americanization of higher education in recent decade, it is highly important to stress on traditionally cultural resources, being identifier. The question on how to insert this traditionally cultural resources into general education has become a main issue for higher education in Indonesia. Traditional education of Indonesia has broad coverage and profound insights, so the biggest challenge is which culture will be inserted into general education. An outstanding and well-known German sociologist, Max Weber, had ever compared Confucianism and Protestant ethics and concluded that "conservative and introvert nature of Confucianism delays China modernization" [16]. One of example and comparator is China, having Confucianism as the mainstream traditional culture, and it shows that inserting classical culture of Confucianism into their general education should exclude their conservative component, if not it will be useless to advance China modernization. Similarly, some scholars have demonstrated that, "It is not too realistic to employ agricultural civilization to order the industrial one, to utilize philosophy not having democratic view in the mod- 
ern term in order to accelerate political democracy, or to use thinking system underestimating the usage of 'science and commercial practice to promote modernization and post-modernization" [17].

\section{Subject of Knowledge Integrity in General Education}

This study reveals that teaching of specifically main subject course can facilitate students to achieve interdisciplinary synthesis of knowledge on general education. This kind of synthesis is, indeed, a dimension of curriculum integrity. Many experts have heatedly debated on subject of curriculum integrity. Fang (2018) believed that subject of curriculum integrity minimally had to cover students. However, other experts alleged that students could not integrated knowledge previously having been integrated by educator, so that curriculum integration was established by educator when designing curriculum [8]. Meng \& Huang (2018) argued, then, that students could not be subject of knowledge integration. He further cited Jonathan Smith, a former rector of Liberal Arts College in University of Chicago, stating, "Students will not individually be expected to integrate anything where faculty cannot or will not conduct" [13]. Mostly, many experts agree upon a view that educator minimally has to be subject of knowledge integration. Zhong Qiquan, for instance, believed that both educators and students had to be integrated subject course [8]. This research's finding demonstrates that students play significant role in knowledge integration of general education. Whereas any educator of basic subject course is involved outside of his/her field, their profound and wide-range interdisciplinary knowledge may inspire students' thinking and broaden their knowledge, and it can be facility function in synthesis of knowledge.

Viewing situation for students coming from different major, instructor of basic subject course in Muhammadiyah University of Yogyakarta can, then, inspire students' interdisciplinary thinking and, at least, presents that knowledge integration of instructor is a pivotal circumstance in the curriculum integration. Besides, instructor of general education can absorb curriculum design, lecturing method, and two-ways interaction of lecturer and students with the concept of general education is another condition required for curriculum integration, and, in this study, design of subject course should actively facilitate synthesis of knowledge of students' interdisciplinary knowledge.

The final basic of curriculum integration is still part of students, so that 
they must consciously view from perspectives of various disciplines, or multidisciplines. By integrating past knowledge and experience with recent issues, students can produce new issue and knowledge, which can be a source of innovation. This analysis postulates that it is hard to determine which segment of synthesis of interdisciplinary knowledge takes place in a real teaching environment. We should consider curriculum integration as a comprehensive process of mutual interaction between educator and students, a site of twoways exchange and meaning construction of human's experience and knowledge, and reducing any dispute on subject of curriculum integration.

\section{Subject course of General Education Practices}

Should general education start from either macro level by reforming educational institution and model or meso level by changing school and department organization, or macro level by constructing curriculum of general education? By observing situation in Muhammadiyah University of Yogyakarta, management may focus on strengthening construction of general education and main curriculum, and it can periodically turn from micro to macro scope of view. It is an effective method to establish purpose of general education. In the level of general education curriculum, it necessary requires to firm relations between subject courses and certain regulations on various types of subject course on general education that can be taken by students from variously different programs and years. Further, design of instructional subject course must consider different background of students. As coming to instruction, demonstration, design, evaluation and form of teaching related to subject course of general education, it should be managed correctly. Construction of principal subject course must accommodate and facilitate students' perspective broadening and interdisciplinary knowledge. A process of study and mechanism of interdisciplinary synthesis of case subject course demonstrates us that absorbing all subject courses with the concept of general education is an effective path to solve issue on "separating general education and main education in different segment".

\section{CONCLUSION}

Any successful implementation of general education does not only depend on institutional design, but also require improvement of education method. Eventually, the final purpose of general education is to set students free from perspective limitation of overload and exaggerate-based education 
and obtain capacity to self-liberate. Clearly speaking, it is hard to achieve such purpose through traditional mode of teaching. Contrastingly, otherwise, it can only be achieved by two-ways communications and communication exchange between students and educators in various circumstances. To achieve "spiritually personal development", students should provide knowledge and wisdom through their daily life experience. Internet as one of technological tools for education, particularly a massive development of MOOCs (Massive Open Online Course), has highly contributed and offered a wide opportunity for universities to achieve high-quality general education. In this case, general education should focus on comprehensive application from a diverse teaching method in future, such as discussion, experience, online learning. An integration of general education and subject based-education cannot be solved in short period of time, but it requires periodical phase to establish general education having Indonesian characteristic.

\section{RECOMMENDATION}

As stated in the research's findings and analysis above, some following suggestions may be as a further consideration:

1. General education should be one of priorities in the next future curriculum development, since university can exercise student character building through general education.

2. General education should be taught by a lecturer having suitably educational background.

3. General education can be turned as university's identity and superiority.

\section{ENDNOTES}

1 H. Fang, "How to Mutually Advance General Education and Major-Based Education/ : A Grounded Theory Study on the Course Level," vol. 14, no. 4, pp. 68-80, 2018.

2 E. A. Hanushek, "General Education, Vocational Education, and LaborMarket Outcomes over the Lifecycle."

3 W. Meng and W. Huang, "Institutional Problems and Solutions of General Education in Chinese Universities," vol. 34, no. 4, pp. 21-28, 2018.

4 O. Malamud and C. Pop-eleches, "General Education Versus Vocational Training/ : Evidence From An Economy In Transition,” vol. 92, no. February, pp. 43-60, 2010.

5 P. R. A. C. Tice, "General Education as a Gateway for Establishing Self-Directedness ," 2017.

6 H. Wang and D. Xie, "Twenty Years of General Education in China/: Progress 
, Problems , and Solutions," no. 6, pp. 9-20, 2018.

7 M. B. Miles, M. Huberman, and J. Saldana, Qualitative Data Analysis: A Method Sourcebook, 3rd ed. Los Angeles: SAGE Publications, 2014.

8 Z. Zhong and M. Sun, "A Rational Examination of Integrating ' Classics' into University General Education Curriculum/ : An Empirical Survey Based on N University," vol. 11, no. 4, pp. 81-89, 2018.

9 Y. Hanafi, "Transformasi Kurikulum Mata Kuliah Pendidikan Agama Islam di Perguruan Tinggi Umum/ : Dari Paradigma Normatif-Doktriner," J. Pendidik. dan Pengajaran, pp. 27-37, 2016.

10 I. Zilic, "General versus Vocational Education: Lessons from a Quasi-Experiment in Croatia," Econ. Educ. Rev., 2017.

11 S. M. Swearer, C. Wang, J. W. Maag, A. B. Siebecker, and L. J. Frerichs, "Understanding the bullying dynamic among students in special and general education,” J. Sch. Psychol., vol. 50, no. 4, pp. 503-520, 2012.

12 E. Ruskovaara and H. Minna, "HEAD teachers managing entrepreneurship education e Empirical evidence from general education,” vol. 55, pp. 155-164, 2016.

13 J. M. Kauffman, D. Ed, M. Felder, and D. Ph, "Inclusion of All Students in General Education/? International Appeal for A More Temperate Approach to Inclusion," vol. 21, no. 2, pp. 1-10, 2018.

14 C. Hall, "PT US CR,” Econ. Educ. Rev., 2016.

15 C. Poondej and T. Lerdpornkulrat, "Kasetsart Journal of Social Sciences Relationship between motivational goal orientations , perceptions of general education classroom learning environment, and deep approaches to learning," Kasetsart J. Soc. Sci., vol. 37, no. 2, pp. 100-103, 2016.

16 L. Vegas, W. Career, T. Academy, and L. Vegas, "General Education Curricula Affecting Satisfaction And Retention OfUndergraduate Students/ : A Review Of Literature," pp. 197-203, 2014.

17 İ. Vairis, "How Actors Of Local Society ( Community) Influence The Development Of Decentralized General Education , And Their Attitude To It .," vol. 140, pp. 570-575, 2014.

\section{REFERENCE}

Fang, H. (2018). How to Mutually Advance General Education and Major-Based Education/ : A Grounded Theory Study on the Course Level, 14(4), 68-80. https://doi.org/10.1080/10611932.2017.1411698

Hall, C. (2016). PT US CR. Economics of Education Review. https://doi.org/10.1016/ j.econedurev.2016.03.005

Hanafi, Y. (2016). Transformasi Kurikulum Mata Kuliah Pendidikan Agama Islam di Perguruan Tinggi Umum/ : Dari Paradigma Normatif-Doktriner. Jurnal Pendidikan Dan Pengajaran, 27-37.

Hanushek, E. A. (n.d.). General Education , Vocational Education , and LaborMarket Outcomes over the Lifecycle. https://doi.org/10.3368/jhr.52.1.0415$7074 \mathrm{R}$

Kauffman, J. M., Ed, D., Felder, M., \& Ph, D. (2018). Inclusion of All Students in 
General Education/? International Appeal for A More Temperate Approach to Inclusion, 21(2), 1-10.

Malamud, O., \& Pop-eleches, C. (2010). General Education Versus Vocational Training/ : Evidence From An Economy In Transition, 92(February), 43-60.

Meng, W., \& Huang, W. (2018). Institutional Problems and Solutions of General Education in Chinese Universities, 34(4), 21-28. https://doi.org/10.1080/ 10611932.2017.1411138

Miles, Matthew B.; Huberman, Michael; Saldana, J. (2014). Qualitative Data Analysis: A Method Sourcebook (3rd ed.). Los Angeles: SAGE Publications.

Poondej, C., \& Lerdpornkulrat, T. (2016). Kasetsart Journal of Social Sciences Relationship between motivational goal orientations, perceptions of general education classroom learning environment, and deep approaches to learning. Kasetsart Journal of Social Sciences, 37(2), 100-103. https://doi.org/10.1016/ j.kjss.2015.01.001

Ruskovaara, E., \& Minna, H. (2016). HEAD teachers managing entrepreneurship education e Empirical evidence from general education, 55, 155-164. https:// doi.org/10.1016/j.tate.2016.01.004

Swearer, S. M., Wang, C., Maag, J. W., Siebecker, A. B., \& Frerichs, L. J. (2012). Understanding the bullying dynamic among students in special and general education. Journal of School Psychology, 50(4), 503-520. https://doi.org/10.1016/ j.jsp.2012.04.001

Tice, P. R. A. C. (2017). General Education as a Gateway for Establishing SelfDirectedness.

Vairis, Ï. (2014). How Actors Of Local Society ( Community) Influence The Development Of Decentralized General Education, And Their Attitude To It ., 140, 570-575. https://doi.org/10.1016/j.sbspro.2014.04.472

Vegas, L., Career, W., Academy, T., \& Vegas, L. (2014). General Education Curricula Affecting Satisfaction And Retention Of Undergraduate Students/ : A Review Of Literature, 197-203.

Wang, H., \& Xie, D. (2018). Twenty Years of General Education in China/ : Progress , Problems , and Solutions, (6), 9-20. https://doi.org/10.1080/ 10611932.2017.1411134

Zhong, Z., \& Sun, M. (2018). A Rational Examination of Integrating “Classics “ into University General Education Curriculum/ : An Empirical Survey Based on N University, 11(4), 81-89. https://doi.org/10.1080/1061193. 2.2017.1411700

Zilic, I. (2017). General versus Vocational Education: Lessons from a Quasi-Experiment in Croatia. Economics of Education Review. https://doi.org/10.1016/ j.econedurev.2017.10.009 
